\title{
Decriminalising Sex between Men in the Former Soviet Union, 1991-2003: Conditionality and the Council of Europe ${ }^{1}$
}

\author{
Benjamin H. Noble
}

Between 1991 and 2003, most former ${ }^{2}$ Soviet states decriminalised sex between men. ${ }^{3}$ Only Uzbekistan and Turkmenistan retain articles in their criminal codes which criminalise this form of sexual congress. The cluster of progressive reforms was surprising, not least because the morally sensitive changes were largely uncontested. Commenting on the possibility of decriminalisation, Igor Kon - the leading Russian academic on sexual minorities - wrote in 1993 (112): 'Even given a favourable outcome, the process is bound to be protracted, problematical and vastly different in the various regions and former republics'. This scenario, however, was not realised. The chapter will explore this group of decriminalisations, interrogating the existing view that legal reform was primarily the result of Council of Europe membership conditionality.

\section{Introduction}

Western influence is regularly invoked to explain progressive legal change in former Soviet states. This can be found in the existing literature on the decriminalisation of sex 
between men in the former Soviet Union (FSU): the Council of Europe $(\mathrm{CoE})$ is often cited as the cause of this reform 'wave' - see, for example: Sanders (2002: 17); Štulhofer and Sandfort (2005: 13); Torra (1998: 77); and Waaldijk (2000: 72). In joining the CoE, post-Soviet states were required to sign the European Convention on Human Rights (ECHR) at the time of accession, and ratify it within a specified timeframe (Croft et al. 1999). In order to ratify the Convention, states entered a harmonisation process to bring their domestic legislation into conformity with the ECHR's substantive provisions, as well as its case law (Drzemczewski 1995). In the case of Dudgeon v. UK in 1981, the European Court of Human Rights (ECtHR) decided that the criminalisation of consensual, private, same-sex sexual intercourse contravened Article 8 of the ECHR. ${ }^{4}$ In effect, this meant that all members and applicant states were required to remove laws criminalising sex between men. Put differently, decriminalisation was - in principle, at least ${ }^{5}$ - a membership condition for the Council of Europe.

Most existing studies argue that $\mathrm{CoE}$ membership requirements were used to export a liberal, Western norm into what were seen as inimical domestic environments. The decriminalisation of sex between men in FSU states is chosen here, therefore, as a putative case of a 'wave' of reforms caused by a single international source - in this case, the CoE. The task of the chapter is to test this explanation by examining and comparing the actual processes of reform with those expected by such an explanation. ${ }^{6}$ The research on which this chapter is based used process-tracing methods (see George and Bennett 2005: 6) to examine data collected on a fieldtrip to the Council of Europe in September 2009, as well as the domestic dynamics of decriminalisation in former 
Soviet states. This methodology is in line with the 'policy-tracking approach' employed by Hughes et al. (2004b: 523) to examine EU conditionality. ${ }^{7}$ Interviews were conducted with non-governmental organisation (NGO) officials, CoE officials, as well as legal and academic specialists on the region. ${ }^{8}$ Documents consulted included texts of criminal codes, NGO reports, NGO newsletters, CoE reports on accession states, accession documents, and media reporting. ${ }^{9}$

From the outset, the CoE membership conditionality argument is distinctly problematic. Firstly, CoE membership conditionality cannot prima facie explain all decriminalisations in the former Soviet Union: Ukraine repealed its law criminalising sex between men well before its membership process began; and Kazakhstan, Kyrgyzstan, and Tajikistan have never had a membership track open to them. Secondly, the account remains incomplete for the other FSU states. That is, in order to understand why these states decriminalised sex between men, it is not enough simply to point to an international organisation's (IO) membership requirements. As the literature on conditionality demonstrates, state compliance with IO conditions is far from a clear and uncontested process (see, for example: Checkel 2000; Epstein 2008; Hughes et al. 2004a, 2004b; Jordan 2003; Killick 1998; Kochenov 2008; and Sasse 2008, 2009). Indeed, $\mathrm{CoE}$ pressure to decriminalise sex between men in the form of conditionality was met with sustained contestation in Romania, with exhortations from parliament that 'we want to join Europe, not Sodom' (see, for example: Long 1998; Nachescu 2005; Stychin 2003; Turescu and Stan 2005). ${ }^{10}$ Thirdly, the non-criminalisation of sex between men is not a distinctly Western norm. For example, the Soviet Russian criminal code promulgated in 1922 did not include a criminalising article, thus departing from 
the late Tsarist practice of criminalisation (Kon 1997); and many East European communist states decriminalised in the 1960s and 1970s (Tatchell 1992). Moreover, the pattern of compliance following Dudgeon was varied. Certain member states - Ireland and Cyprus, in particular - vehemently resisted what they saw to be a legal reform incompatible with their societies' morality (McLoughlin 1996). ${ }^{11}$

It will be argued that the decriminalisation of sex between men in FSU states was not a unitary, wholly Western-inspired 'wave'. More specifically, very little evidence can be marshalled to support the CoE membership conditionality explanation. A more nuanced picture of reform emerges by placing this cluster of legal changes in the longer narrative of Soviet laws regulating sexual practices, by revealing the patchiness of CoE pressure in this area, and by tracing legislative reform dynamics in each state - a style of scholarship which is in line with Lacey's (2009: 942) call for 'historicising criminalisation'. This chapter will deal mainly with evidence relating to the Council of Europe's activities, although summary sections on legal history and domestic reform processes are included.

\section{History}

The legal regulation of sex between men has a complex and varied history in FSU states. In Russia, for example, the legal status of this sexual practice alternated from Tsarist criminalisation to Bolshevik decriminalisation to Stalinist recriminalisation and back to post-Soviet decriminalisation (Kon 1997); certain other states, however, 
experienced consistent criminalisation (Healey 2001). The brief sketch of this history below will simply provide stage-setting points for the main section on the Council of Europe. ${ }^{12}$ This will involve making three points: firstly, that the legal regulation of sex between men varied temporally and geographically across states in the region; secondly, that societal sentiment towards sexual minorities in the late Soviet and early post-Soviet periods was not apparently conducive to progressive reform; and, thirdly, that it is possible to locate domestic ideational sources for reform in this area of criminal law.

Following the abrogation of the Tsarist criminal code in October 1917, an article criminalising sex between men was not included in the first Soviet Russian code of 1922 (Healey 1993: 31-32). Similarly, the criminal codes of the Ukrainian Soviet Socialist Republic (SSR), the Belorussian SSR, and the Armenian section of the Transcaucasian Soviet Federative Socialist Republic did not criminalise this sexual practice. The criminal codes of all other Union republics, however, contained criminalising articles (De Jong 1982; Healey 2001). This institutional variation ended, however, on 7 March 1934, when sex between men was made a criminal offence across the Soviet Union - part of the wider Stalinist 'sexual thermidor' (Stites 1990: 376). ${ }^{13}$

Following criminalisation, the subject was removed from public debate (Kon 1997). Thus, as Essig (1999: 7) writes, 'homosexuality existed outside the public's view, glimpsed only fleetingly in a law that forbade it'. Indeed, the 'concept of homosexuality as a danger to the socialist state persisted' through the process of de-Stalinisation (Gessen 1994: 9). This 'discursive void' (Baer 2009: 44) was only broken during glasnost' (openness) in the late 1980s. However, early press articles argued that the 
decriminalisation of sex between men would lead to the spread of this 'infectious' 'perversion' (Tornow 1991). Indeed, this negative discourse was perpetuated and reinforced by the emergence of HIV/AIDS. High-profile medical experts - such as Academician Nikolai Burgasov (erstwhile Deputy Health Minister and Chief Hygiene Doctor of the USSR) - stated publicly that the virus did not pose a threat to the Soviet people, 'so far as homosexuality was a criminal offence' (Kon 1993: 95). An indication of societal attitudes towards the subject is captured by survey results from Russia conducted at the end of 1992, in which 'gay men' came second only to 'neo-fascists' as the most disliked group (Bahry et al. 1997). This would not seem to be the most propitious environment for progressive reform.

There were, however, domestic initiatives to decriminalise sex between men in the Soviet era. It is possible to trace reformist sentiment through, for example, a 1973 legal textbook, which noted the curious jurisprudential status of the offence, ${ }^{14}$ and efforts by Professors Alexei Ignatov and Igor Kon to publish research on the topic as a means of urging reform (Gessen 1994; Healey 2001; Kon 1997). Although this progressive thought had little initial impact on official policy, perestroika (restructuring) provided a juncture for more liberal ideas. Thus, for example, Kon (1997: 228) notes that a 'draft of the revised Russian Criminal Code, prepared by a commission of lawyers in the mid1980s, excluded' the article criminalising consensual sex between men in the Russian Soviet Federative Socialist Republic (RSFSR). This liberalising vein, moreover, was not restricted to the RSFSR. In 1990, a conference titled 'Sexual Minorities and Society: the Changing Attitudes toward Homosexuality in $20^{\text {th }}$ Century Europe' was hosted by the Institute of History of the Estonian Academy of Sciences. The meeting gathered both 
Soviet delegates and Western academics and activists ${ }^{15}$ in what was framed as a sober scientific event to discuss various dimensions of sexuality; in practice, it served as an opportunity to discuss the possibility and necessity of removing laws criminalising sex between men (interview with Jeffrey Weeks, 2009).

Placing post-Soviet reform into a longer historical narrative - however brief its exposition - is vital. It displays historical experience of the non-criminalisation of sex between men in certain regions of the former Soviet Union well before the emergence of such a norm centred on ECHR case law. Furthermore, it is possible to appreciate both the difficulties and possibilities of reform in the late Soviet and early post-Soviet periods, thus setting the context for an analysis of putative international influence.

\section{The Council of Europe and conditionality}

The CoE membership conditionality explanation implies a particular temporal pattern of reform - that is, a distinctive sequential logic. In order for this explanation to be robust, the implied causal 'steps' (George and Bennett 2005: 207) between the putative cause Council membership condition - and effect - the decriminalisation of sex between men - must be present in each case of reform. This central section will discuss whether the argument found in the existing literature is compatible with process-level evidence of the CoE's role in the decriminalisation of sex between men in the former Soviet Union. 
The CoE did not grant automatic membership to post-communist states. ${ }^{16}$ States interested in joining the Council were granted 'special guest status', facilitating basic institutional contact and reform advice (Manas 1996). As a formal pre-condition of membership - and in line with Article 3 of the organisation's Statute (1949) - applicant states had to 'accept the principles of the rule of law and of the enjoyment by all persons within its jurisdiction of human rights and fundamental freedoms'. At the same time, the Council was conscious of the need to integrate post-communist states quickly for its own post-Cold War legitimacy and longevity (Croft et al. 1999). There was also an institutional belief held by many in the Council that an inclusive enlargement policy would help states reform as members of the organisation (Checkel 1999). ${ }^{17}$

This combination of exclusivity and inclusivity was problematic. On the one hand, the Council was expected - as Storey (1995: 137) puts it - to "play the role of principal democratic auditor (or human rights 'Bundesbank') of European states'. ${ }^{18}$ Membership would, therefore, be an exclusive, respectable mark of levels (political, legal, and judicial) already achieved. On the other hand, there was pressure for the Council to become an embodiment of pan-European unity and an active agent in reform (Simpson 2001). In this inclusive vision, the main criterion for membership became simply an aspiration to achieve liberal-democratic ideals (Tarschys 1995). This constituted, quite clearly, a jumble of roles and requirements, which resulted in a compromise: the Council would admit post-communist states quickly but with conditions attached to their membership. 
The Council of Europe's variant of conditionality was peculiar. Unlike the European Union's (EU) ex ante form of conditionality, the CoE included considerable elements of ex post conditionality. ${ }^{19}$ As Vachudova (2005: 133) notes, the Council 'often settled for only a commitment to change domestic policies in the future'. Compliance with accession commitments would then be monitored by both the Parliamentary Assembly of the Council of Europe (PACE) and the Committee of Ministers (Croft et al. 1999). Clearly, this form of conditionality was dictated by the two competing views on the organisation's enlargement noted above. ${ }^{20}$

The Council was also particular in its use of 'tailored' conditions. In other words, it applied different conditions for different aspirant states (Meron and Sloan 1996). These differences were determined by the findings of rapporteurs from PACE sent to investigate conditions in applicant states, as well as the results of 'eminent jurists' reports'. Overall, the trend was for more stringent conditions to apply to later-joining states (Storey 1995).

There is no automatic link between conditionality and compliance. Hughes et al. (2004a), for example, warn against assuming the (positive) causal effects of conditionality on state behaviour. This is particularly apparent for an ostensibly 'weak institution' (Sasse 2011: 171) such as the Council of Europe, with limited mechanisms for sanctioning non-compliance. And yet, Schimmelfennig et al. (2006: 7) are wrong to argue that the $\mathrm{CoE}$ was limited to socialisation strategies other than conditionality, without the high material benefits of institutions such as the EU and the North Atlantic Treaty Organization (NATO). As Kelley (2004) demonstrates, the Council was 
successful in bringing about change using conditionality in certain circumstances. For example, Kelley concludes that 'unrelenting' (2004: 444) CoE conditionality in Latvia was successful in amending citizenship legislation. This insight reinforces the need to pay close attention to the specific processes of conditionality - in particular, the 'politics of conditionality' (Sasse 2008: 842; see also Kochenov 2008). With this very focus, however, it is clear that compliance with the norm created by Dudgeon would be problematic since the judgment was contested by a number of existing Council member states. This lack of 'taken-for-grantedness' (Epstein 2008: 15) diminished the authority with which the Council could impose conditions for membership.

Hughes et al. (2004b: 526) distinguish between 'formal' and 'informal' EU conditionality. Whereas the former relates to the black letter of conditions, the latter 'includes the operational pressures and recommendations applied by actors'. Thus, we might say that formal conditions are animated by informal conditionality. In the legal harmonisation process associated with ECHR ratification, it is possible that Council officials highlighted or emphasised particular areas for reform in their interactions with officials from 'special guest status' states. Similarly, Checkel (2000) - writing about Council efforts in Ukraine to abolish the death penalty - describes the "conditionalityplus-dialogue approach'. In essence, this combines conditionality with other socialisation techniques, such as persuasion, social learning, and social influence. Vachudova (2005: 285, note 74) terms this 'soft conditionality'. For Kelley (2004: 449), this mix was the norm: 'institutions never applied conditionality without also relying on softer efforts'. Checkel writes of CoE attempts to 'convince Ukrainian elites that abolishment [sic] of capital punishment was the appropriate thing to do as a 
democratising, rule-of-law polity'. Peshkopia and Imami (2008) corroborate the use of this mixed strategy, using the case of Albania. They note, furthermore, that the Council attempted to socialise the elites of accession states, whilst insulating this reform process - particularly for morally sensitive pieces of legislation - from the public.

If Council of Europe membership conditionality was responsible for the decriminalisation of sex between men this group of states, then we would expect to see a particular pattern of compliance: either states would decriminalise whilst holding 'special guest status' - therefore subject to pressure from PACE rapporteurs and helped by legal experts through the Demosthenes-bis ${ }^{21}$ programme (Manas 1996); or, for states which had not decriminalised before gaining membership, we would expect decriminalisation to be made an accession commitment, with subsequent compliance. Table 1 presents the relevant data for this first stage of analysis.

\section{TABLE 1 NEAR HERE}

As noted above, four states fit neither pattern: Kazakhstan; Kyrgyzstan; Tajikistan; and Ukraine. Six states fit the first pattern variant - decriminalisation during 'special guest status': Azerbaijan; Belarus; ${ }^{22}$ Estonia; Latvia; Moldova; and Russia. Of course, noting a pattern match is not the same as finding a causal relationship. In order to evaluate the latter, we need to drill down to a different level of data: evidence of the Council's activities around the issue of decriminalisation in accession states. The three remaining states - Armenia, Georgia, and Lithuania - are candidates for the second pattern variant, but assessing this requires information on the content of accession agreements. The 
following section will examine this more fine-grained evidence of the Council's efforts, drawing on archival sources and the accounts of officials involved with accession processes.

On 1 October 1981, PACE adopted Recommendation 924, 'On discrimination against homosexuals'. Inter alia, this called on $\mathrm{CoE}$ member states to remove laws criminalising sex between men, in line with - although pre-dating - the ECtHR's judgment in Dudgeon v. UK. This constituted a declaratory political precedent for the Assembly's position on the legal regulation of sex between men. Quite clearly, the statement was made with reference to existing members. With later enlargement to postcommunist space, however, PACE's position became ambiguous. Should it require decriminalisation before accession or simply exert pressure when states became members? An initiative advocating the former approach can be seen in Written Declaration 227 (18 February 1993), 'On homosexual rights in the new democracies'. This document suggested that attention to the legal status of sex between men should be included in accession reform considerations. Torra (1998) cites this as a clear sign of Council pressure. However, Torra fails to note that the document was not adopted by PACE, but, rather, signed by only eleven members of the Assembly. As such, although non-criminalisation technically formed part of the ECHR acquis, political support for emphasising decriminalisation as an accession condition was weak. Indeed, further research reveals that the motivation for Written Declaration 227 came from an NGO the International Lesbian and Gay Association (ILGA) - which lobbied an Austrian parliamentarian, Mrs. Graenitz, to submit the document for members of the Assembly to sign (EURO-Letter 7 1992). ${ }^{23}$ 
By the end of the 1990s, political will in this area had increased significantly. In a meeting of the Sub-Committee on Human Rights of the Committee on Legal Affairs and Human Rights (CLAHR) in Paris on 14 October 1999, members discussed the situation of sexual minorities in CoE member states. The situation in 'special guest states' was also discussed. The event provided a wealth of information on continued discrimination, and displayed a renewed consensus on advocating the removal of discriminating legal provisions. Similar points were made by Mr. Csaba Tabajdi rapporteur for CLAHR - in his report, 'Situation of lesbians and gays in Council of Europe member states', presented to PACE on 6 June 2000. This formed the basis for a debate in the Assembly on 30 June, and the adoption on 26 September of Recommendation 1474. Inter alia, this called on member states to 'remove all legislative provisions rendering homosexual acts between consenting adults liable to criminal prosecution' (part 11 iii b), and 'to release with immediate effect anyone imprisoned for sexual acts between consenting homosexual adults' (part 11 iii c).

Recommendation 1474 is interesting for another reason. The document notes: 'Under the accession procedure for new member states, the Assembly ensures that, as a prerequisite for membership, homosexual acts between consenting adults are no longer classified as a criminal offence' (part 4). ${ }^{24}$ This equates to ex ante conditionality. It is, furthermore, important to stress that this is an apparent statement on existing procedures, rather than a recommendation for future practice. ${ }^{25}$ And yet, we have already noted PACE's ambiguous position on the place of decriminalisation in 
accession. It is clear by looking at accession documents, in fact, that this characterisation of decriminalisation conditionality is at best misleading, at worst false.

Following a state's application to join the Council of Europe, the Committee of Ministers is mandated by Statutory Resolution 51 (30 A) to seek the advice of PACE in the form of an official 'Opinion'. We would expect to find evidence of Council pressure on states to decriminalise sex between men in these documents. There are, however, few references to such efforts. None are present in the documents relating to the accession of Estonia, Georgia, Latvia, Lithuania, Russia, and Ukraine. ${ }^{26}$ This is particularly puzzling for Georgia and Lithuania, since sex between men remained a criminal offence at the time of the states' accession to the CoE. Decriminalisation was clearly, therefore, not a prerequisite for membership, neither was it an explicit accession commitment. This is made even more puzzling given the fact that a decriminalisation commitment was attached to Romania's accession in 1993 . Why was such a commitment not extended to states in a similar position? Peter Schieder - Honorary President of PACE - revealed in a speech that a focus on decriminalising sex between men often fell victim to intraAssembly politics, and was, therefore, not always included in accession agreements (Schieder 2009). This, again, highlights the importance of paying attention to the politics of conditionality.

The first reference to efforts to decriminalise sex between men in a post-Soviet state can be found in the CLAHR opinion on Moldova's application, written by Mr. Columberg and Mr. Jeszensky (15 June 1995). They note: 
We have received a letter from a human rights group fighting for the rights of homosexuals, which pointed out that the amended Soviet Criminal Code still penalises homosexual relationships between consenting adults (in November 1994). The Moldova authorities have assured us that this provision is not implemented, and that the new draft Criminal Code decriminalises such relationships. We expect that no amendment will be introduced to the new draft Code on this point. This we consider covered in the commitment to adopt a new Criminal Code in conformity with Council of Europe standards.

A decriminalisation condition was, therefore, not included in the Assembly's 'Opinion' (No. 188) on Moldova's application for membership (adopted by PACE on 27 June 1995). Wider research reveals that the letter mentioned was sent by Alexandra Duda on behalf of ILGA-Europe (EURO-Letter 32 1995).

The second reference is found in the CLAHR opinion on Azerbaijan's application, written by Mr. Georges Clerfayt (presented on 27 June 2000). Noting the continued presence of an article criminalising sex between men in the state's criminal code, the rapporteur recommended adding an accession commitment of decriminalisation to the state's accession document (see Amendment E). However, such a reference to decriminalising sex between men was not included in PACE's 'Opinion' (No. 222). This was due, it seems, to the fact that a new criminal code had already been adopted 
on 30 December 1999, which did not criminalise consensual sex between men; it was to come into force on 1 September 2000.

The only other references relate to Armenia's accession. The CLAHR opinion, written by rapporteur Mr. Michael Spindelegger, notes in section 34 that sex between men remained a criminal offence at the time (6 June 2000). Furthermore, the Ministry of Interior is reported as stating that four men in 1999 were charged for consensual sex, and awaiting trial. As such, Spindelegger recommended that decriminalisation be made an explicit accession commitment. PACE's 'Opinion' (No. 221) on Armenia's application includes the following obligation: 'to adopt, within one year of its accession, the second (specific) part of the Criminal Code, thus abolishing de jure the death penalty and decriminalising consensual homosexual relationship between adults' (part 13 iii a).

Armenia did not comply. A report by the Committee on the Honouring of Obligations and Commitments by Member States of the Council of Europe, written by Mrs. Irena Belohorska and Mr. Jerzy Jaskiernia (presented to PACE on 13 September 2002), found that, although the new draft criminal code decriminalised sex between men in line with its accession commitment, the code had not yet been adopted (see section 76). The rapporteurs also noted that, since 1994, 48 people had been convicted under Article 116, with 15 prosecuted in 1999 and six in 2000 (see section 77). PACE's Resolution 1304 (26 September 2002) on the 'Honouring of obligations and commitments by Armenia', therefore, called on the Armenian government to adopt the new criminal code as soon as possible, thereby decriminalising sex between men. This change was confirmed in the 
same committee's report of 12 January 2004, written by rapporteurs Mr René André and Mr Jerzy Jaskiernia (see section G, paragraphs 220-222).

Information provided by Council officials in interviews mirrors this picture of patchy attention. Some reported that the decriminalisation of sex between men was never discussed. A former senior official in the Human Rights Law and Policy Division stated that nothing specific was mentioned in the accession of FSU states, due in part to the unconsolidated nature of the ECHR's case law. In other words, the issue was not pressed given the emergent norm's continued contestation. Guy de Vel - former Director General of Legal Affairs - reported that the legal regulation of sex between men was not part of the reform assistance given by his department; and yet this is precisely the section of the Council which we would expect to be active. Finally, Georges Clerfayt - the CLAHR rapporteur for Azerbaijan's accession - stated that decriminalisation was 'never raised and discussed' with officials from Azerbaijan, despite his proposal for a decriminalisation commitment noted above.

Other officials, however, argued that decriminalisation was discussed with some acceding FSU states. A former CLAHR official recalled that the issue was raised with certain states, in particular Romania and Moldova. Indeed, at the 1999 Paris meeting of the Sub-Committee on Human Rights referred to above, the Chair - Mr. Jaskiernia remarked that the sub-committee 'had always taken a special interest in the situation of homosexuals, particularly when new member states joined the Organisation'. ${ }^{27}$ An official in the Office of the Commissioner for Human Rights noted the increased confidence of the Council in pressing the issue with FSU states as enlargement 
progressed. This was confirmed by Catherine Maffucci-Hugel - former Co-Secretary of the Committee on Legal Affairs and Human Rights of the Parliamentary Assembly and a senior official in the Directorate of Democracy and Political Affairs.

What explains this mix of views? It could be that certain officials were unaware of relevant activities, or that they have since forgotten. Either way, both interpretations are consistent with the fact that the decriminalisation of sex between men was, at most, a low-profile issue in the Council's enlargement process. This can be contrasted with the high visibility accorded to the abolition of the death penalty (see Checkel 2000; Peshkopia and Imami 2008; Saari 2008) and minority rights (Kelley 2004; Sasse 2008). Indeed, an anecdotal piece of evidence uncovered in an interview with Nigel Warner ILGA-Europe's CoE adviser - supports this view. After presenting a report to PACE, Terry Davis - the-then Political Affairs Committee rapporteur for Georgia's accession was approached by Warner and asked why a decriminalisation commitment was not included in Georgia's accession document, to which Davis replied, 'I'm sorry: I forgot'.

This evidence is surprising. The Council of Europe is widely regarded as the cause of the 'wave' of decriminalisations of sex between men in post-Soviet space through the use of membership conditionality; yet, there is remarkably little evidence from Strasbourg - of both formal and informal conditionality - to support this view. In addition, there is no evidence that the Council took part in wider socialising efforts around decriminalising sex between men in its assistance programmes with FSU states. ${ }^{28}$ Socialisation around sexual minorities more broadly by the CoE has only 
recently begun (see, for example, the March 2010 report by Mr. Andreas Gross for CLAHR, 'Discrimination on the basis of sexual orientation and gender identity').

The influence of the Council of Europe was much less powerful, more complex, and distinctly messier than suggested by the membership conditionality model. However, other means of Council influence can be posited: for example, what Haggard et al. (1993: 182) call 'anticipatory adaptation' - 'a country's unilateral adoption of a set of norms associated with membership in an organisation prior to its actually being accorded full status in that organisation, or even receiving guarantees of entry' - or what Vachudova (2005: 65) terms 'passive leverage'. ${ }^{29}$ The worry is, however, that without sufficient data - these arguments automatically assume international influence as the source of change. Exploring the domestic dynamics of reform is, therefore, the next necessary step. The following section summarises this information.

\section{Domestic processes of reform}

The plausibility of process-tracing analysis depends on detail (Checkel 2005: 4). As such, this short summary can only provide a cursory overview of domestic processes of reform. ${ }^{30}$ Despite these limitations, process-level evidence paints a clear and largely uniform picture of decriminalisation: quiet, elite-led reform, largely insulated from public discussion and emergent civil society activity, as part of wider institutional liberalisation following the collapse of the Soviet Union. ${ }^{31}$ The problems of negative politicisation seen in Romania were, on the whole, absent from decriminalisations in 
FSU states. And yet, the causes of this cluster of legal reforms varied across post-Soviet space. The 15 FSU states can be placed into four groups: firstly, those in which the decriminalisation of sex between men was largely a function of domestic elite initiative (Estonia, Latvia, Russia, and Ukraine); secondly, those in which international influence - the Council of Europe, in some cases - tipped the balance of domestic interests in the favour of progressive reform (Armenia, Azerbaijan, Belarus, Georgia, Lithuania, and Moldova); ${ }^{32}$ thirdly, those Central Asian states for which the Model Criminal Code of the Inter-Parliamentary Assembly of the Commonwealth of Independent States (IPACIS) provided the influential model for reform (Kazakhstan, Kyrgyzstan, and Tajikistan), ${ }^{33}$ and, finally, the two states which have not decriminalised sex between men (Turkmenistan and Uzbekistan).

Previous scholarship on this topic has tended to lump post-Soviet states together. However, the research which this section summarises demonstrates the heterogeneity of processes involved in decriminalising sex between men; this, in turn, underlines the need to disaggregate the concept of post-Soviet space. For example, in Ukraine - the first state to decriminalise - reform was motivated by the Rada's (parliament) Committee on Health Issues' belief that decriminalising this form of sexual activity was crucial to combating the emergent HIV/AIDS epidemic (Nash Mir 2004: 4). Thus, an epidemiological argument prevailed over historically inculcated notions of legal moralism. Russian decriminalisation - considered by Štulhofer and Sandfort (2005: 10) to be the '[p]aradigmatic case' of external reform pressure - was primarily the result of domestic reform initiatives. ${ }^{34}$ Armenia's experience comes closest to the pattern expected from formal CoE membership conditionality, albeit with a notable delay 
between membership and decriminalisation. Such variation should not be surprising, however, given the historical differences noted in the history section of this chapter and the different paths taken in the transition from Soviet regimes.

\section{Conclusions}

The conditionality model might seem like an appealing explanatory framework at first sight. It presents a simple story: ECHR case law prohibits the criminalisation of consensual sex between men; most post-Soviet states decriminalised this activity around the same time as many of them joined the Council of Europe; therefore - so the story goes - this 'wave' of reforms was caused by Council membership conditionality. Sanders (2002: 17), for example, writes: 'During the 1990s the Council of Europe's [membership] requirements were responsible for the almost total repeal of offending criminal laws in eastern Europe'. However, this chapter has shown the story to be deeply flawed. Existing works often ignore the domestic dynamics of reform, as well as the various legal and ideational heritages of post-Soviet states, and the varying political weight attached by the $\mathrm{CoE}$ to this area in accession processes. This is not to deny the Council's influence completely. Rather, the chapter has challenged the extent and nature of the CoE's influence as described in existing literature.

It is naïve to presume that liberal reforms are the result of Western influence. To be sure, the collapse of communism instigated an unparalleled period of legal interconnectivity between East and West (see, for example, Ajani 1995). Moreover, the 
'critical juncture' 35 experienced by Soviet criminal law certainly allowed an increased opportunity for international influence, whether in the form of 'linkage' or 'leverage' (Way and Levitsky 2007). Yet, reform models were not only to be found abroad: jurists could sometimes draw on domestic precedent, as well as domestic and regional reformist sentiment. ${ }^{36}$ By placing this group of reforms in the context of a longer-term narrative of policy development (Pierson 2005) - albeit in a very short version in this chapter - it is possible to appreciate the complexities and possibilities of progressive change. It appears that, without this historical context, previous scholarship has mistakenly emphasised the role of exogenous reform models and sources. As such, the findings underscore the advantages gained from 'historicising criminalisation' (Lacey 2009: 942).

The chapter's findings also relate to the wider scholarship on the diffusion of criminal law policies. As Dubber and Farmer (2007: 5) write: 'Systems of criminal law do not develop in isolation from each other but are embedded in power relations between different states or between states and their colonies'. Indeed, Grattet et al. (1998) move a step further, suggesting that 'criminalization is best viewed as a process of institutionalization that involves the diffusion of legal forms and practices across polities comprising an interstate system'. Although it is necessary to acknowledge the growing international interdependence of criminal law - that is, of moving 'beyond domestic law' (see the concluding chapter of this collected edition) - there is a danger of jumping to conclusions. It is vital, in other words, to distinguish between policy convergence and policy interdependence. As Pravda (2001: 27) warns, it can be easy 'to mistake policy confluence for policy influence'. This chapter has demonstrated the 
importance of paying close attention to process-level evidence, in order to distinguish between hypotheses concerning the aetiology of criminal law reform.

The above analysis relates to formal legal reforms. However, the phenomena of criminalisation and decriminalisation are clearly much more complex than the simple letter of the law. Lacey (2009: 959-60) reminds us that they are 'complex social institution[s]', including both formal and substantive dimensions. This is certainly apparent in post-Soviet states. Regarding Kyrgyzstan, for instance, Robert Oostvogels notes that ' $\mathrm{n}] \mathrm{o}$ measures were taken to spread awareness among the general population' that sex between men had been decriminalised (Human Rights Watch 2008: 30). As a result, Vladimir Tyupin (referring to the situation in Tajikistan) reports that many members of society - including gay men themselves - 'do not know that homosexuality is legal'. Furthermore, regarding Belarus, Lalo and Schitov (2005) report that convictions for sex between men 'in some instances [...] refer to consensual homosexual intercourse', using data provided by the Ministry of Justice for the period 1996 to 2000.

Decriminalisation has been analysed far less frequently than criminalisation (see, for example, Jenness 2004: 149). As Brown (2007) demonstrates for the American 'overcriminalisation' literature, instances and processes of decriminalisation have largely been ignored by scholars, to the clear detriment of analytical precision. Although this chapter has focused on one particular dimension of this process, it highlights both the possibilities and pitfalls of emerging scholarship on the international dimensions of decriminalisation. 


\section{References}

Adamczyk, A. and Cassady, P. (2009) 'Shaping Attitudes About Homosexuality: The Role of Religion and Cultural Context', Social Science Research 38(2): 338-351.

Ajani, G. (1995) 'By Chance and Prestige: Legal Transplants in Russia and Eastern Europe', The American Journal of Comparative Law 43(1): 93-117.

Baer, B. (2009) Other Russias: Homosexuality and the Crisis of Post-Soviet Identity. Basingstoke: Palgrave Macmillan.

Bahry, D., Boaz, C. and Gordon, S. (1997) 'Tolerance, Transition, and Support for Civil Liberties in Russia', Comparative Political Studies 30(4): 484-510.

Bowring, B. (2003) 'Rejected Organs? The Efficacy of Legal Transplantation and the

Ends of Human Rights in the Russian Federation', in Örücü, E. (ed.) Judicial Comparativism in Human Rights Cases. London: UKNCCL, BIICL.

Brown, D. (2007) 'Democracy and Decriminalization', Texas Law Review 86(2): 223275. 
Capoccia, G. and Kelemen, D. (2007) 'The Study of Critical Junctures: Theory, Narrative, and Counterfactuals in Historical Institutionalism', World Politics 59(3): 341-369.

Capoccia, G. and Ziblatt, D. (2010) 'The Historical Turn in Democratization Studies: A New Research Agenda for Europe and Beyond', Comparative Political Studies 43(8-9): 931-968.

Checkel, J. (1999) 'Norms, Institutions, and National Identity in Contemporary Europe', International Studies Quarterly 43(1): 83-114.

Checkel, J. (2000) ‘Compliance and Conditionality’, ARENA Working Paper WP 00/18.

Checkel, J. (2005) 'It's the Process Stupid! Process Tracing in the Study of European and International Politics', ARENA Working Paper WP 05/26.

CLAHR Doc. 7325 (1995) 'Opinion on the application of Moldova for membership of the Council of Europe'. Online. Available HTTP:

<http://assembly.coe.int/main.asp?Link=/documents/workingdocs/doc95/edoc7325.htm $>$ (accessed 21 November 2011).

CLAHR Doc. 8756 (2000) 'Opinion on Armenia's application for membership of the Council of Europe'. Online. Available HTTP: 
<http://assembly.coe.int//main.asp?link=http://assembly.coe.int/Documents/WorkingDo

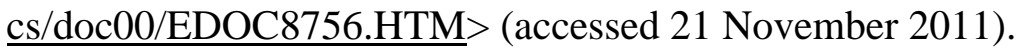

CLAHR Doc. 8757 (2000) 'Opinion on Azerbaijan's application for membership of the Council of Europe'. Online. Available HTTP:

<http://assembly.coe.int//main.asp?link=http://assembly.coe.int/Documents/WorkingDo

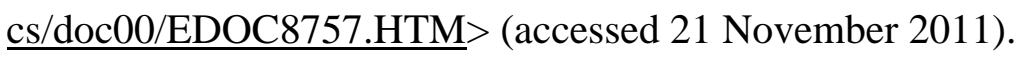

CLAHR report (2000) 'Situation of lesbians and gays in Council of Europe member states'. Online. Available HTTP:

<http://assembly.coe.int//main.asp?link=http://assembly.coe.int/Documents/WorkingDo cs/doc00/edoc8755.htm> (accessed 21 November 2011).

CLAHR report (2010) 'Discrimination on the basis of sexual orientation and gender identity'. Online. Available HTTP:

<http://assembly.coe.int/Main.asp?link=/Documents/WorkingDocs/Doc10/EDOC12185

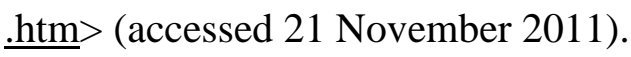

CLAHR Sub-Committee on Human Rights (2000), meeting minutes from 14 October, 'Situation of lesbians and gays in Council of Europe member states' (copy on file with the author). 
Clerfayt, G. CLAHR rapporteur for Azerbaijan. Transcript of a research interview carried out for Noble (2010) on 16 December 2009, and a follow-up interview on 20 December 2011.

Committee on the Honouring of Obligations and Commitments by Member States of the Council of Europe Doc. 9542 (2002) 'Honouring of obligations and commitments by Armenia'. Online. Available HTTP:

< $\underline{\text { http://assembly.coe.int//Main.asp?link=http://assembly.coe.int/Documents/WorkingDo }}$ cs/doc02/EDOC9542.htm> (accessed 21 November 2011).

Committee on the Honouring of Obligations and Commitments by Member States of the Council of Europe Doc. 10027 (2004) 'Honouring of obligations and commitments by Armenia'. Online. Available HTTP:

<http://assembly.coe.int//Main.asp?link=http://assembly.coe.int/Documents/WorkingDo cs/doc04/EDOC10027.htm> (accessed 21 November 2011).

Croft, S., Redmond, J., Wyn Rees, G. and Webber, M. (1999) The Enlargement of Europe. Manchester: Manchester University Press.

De Jong, B. (1982) “An Intolerable Kind of Moral Degeneration’: Homosexuality in the Soviet Union', Review of Socialist Law 4: 341-357. 
De Muniz, P. (2004) 'Judicial Reform in Russia: Russia Looks to the Past to Create a New Adversarial System of Criminal Justice', Willamette Journal of International Law and Dispute Resolution 11: 81-122.

De Vel, G. Former Director General of Legal Affairs, Council of Europe. Transcript of a research interview carried out for Noble (2010) on 4 June 2009.

Drzemczewski, A. (1993) 'The Council of Europe's Co-operation and Assistance Programmes with Central and Eastern European Countries in the Human Rights Field: 1990 to September 1993', Human Rights Law Journal 14.

Drzemczewski, A. (1995) 'Ensuring Compatibility of Domestic Law with the European Convention on Human Rights Prior to Ratification: The Hungarian Model', Human Rights Law Journal 16.

Dubber, M. and Farmer, L. (2007) 'Introduction: Regarding Criminal Law Historically', in Dubber, M. and Farmer, L. (eds) Modern Histories of Crime and Punishment. Stanford CA: Stanford University Press.

Dudgeon v. United Kingdom (1981) 4 E.H.R.R. 149. Cited here from the judgment of the Court (Plenary), 22 October. Online. Available HTTP:

$<$ http://cmiskp.echr.coe.int/tkp197/view.asp?action=html\&documentId=695350\&portal =hbkm\&source=externalbydocnumber $\&$ table=F69A27FD8FB86142BF01C1166DEA3 98649> (accessed 21 November 2011). 
Engelstein, L. (1995) 'Soviet Policy Toward Male Homosexuality: Its Origins and Historical Roots', Journal of Homosexuality 29(2): 155-178.

Epstein, R. (2008) In Pursuit of Liberalism: International Institutions in Postcommunist Europe. Baltimore, MD: The Johns Hopkins University Press.

Essig, L. (1999) Queer in Russia: A Story of Sex, Self, and the Other. Durham, NC: Duke University Press.

EURO-Letter 7 (1992), July. Online. Available HTTP:

<http://www.ilga-europe.org/europe/publications/euro_letter $>$ (accessed 21 November 2011).

EURO-Letter 32 (1995), March. Online. Available HTTP:

<http://www.ilga-europe.org/europe/publications/euro_letter $>$ (accessed 21 November 2011).

EURO-Letter 43 (1996), August. Online. Available HTTP:

<http://www.ilga-europe.org/europe/publications/euro_letter> (accessed 21 November 2011).

Fellmeth, A. (2008) 'State Regulation of Sexuality in International Human Rights Law and Theory', William and Mary Law Review 50: 797. 
Former CLAHR official, Council of Europe. Transcript of a research interview carried out for Noble (2010) on 16 September 2009.

Former senior official in the Human Rights Law and Policy Division, Council of Europe. Transcript of a research interview carried out for Noble (2010) on 17 September 2009.

George, A. and Bennett, A. (2005) Case Studies and Theory Development in the Social Sciences. Cambridge, MA; London: MIT Press.

Gerring, J. (2007) Case Study Research: Principles and Practices. New York, NY: Cambridge University Press.

Gessen, M. (1994) The Rights of Lesbians and Gay Men in the Russian Federation. San Francisco, CA: IGLHRC.

Grattet, R., Jenness, V. and Curry, T. (1998) 'The Homogenization and Differentiation of Hate Crime Laws in the United States, 1978 to 1995: Innovation and Diffusion in the Criminalization of Bigotry', American Sociological Review 63(2): 286-307.

Haggard, S., Levy, M., Moravcsik, A. and Nikolaidis, K. (1993) 'Integrating the Two Halves of Europe: Theories of Interests, Bargaining, and Institutions', in Keohane, R., 
Nye, J. and Hoffmann, S. (eds) After the Cold War: International Institutions and State Strategies in Europe, 1989-1991. London; Cambridge, MA: Harvard University Press.

Hall, P. (2008) 'Systematic process analysis: when and how to use it', European Political Science 7(3): 304-317.

Healey, D. (1993) 'The Russian Revolution and the Decriminalisation of Homosexuality', Revolutionary Russia 6(1): 26-54.

Healey, D. (2001) Homosexual Desire in Revolutionary Russia: The Regulation of Sexual and Gender Dissent. Chicago, IL; London: The University of Chicago Press.

Hughes, J., Sasse, G. and Gordon, C. (2004a) Europeanization and Regionalization in the EU's Enlargement to Central and Eastern Europe: The Myth of Conditionality. Basingstoke: Palgrave Macmillan.

Hughes, J., Sasse, G. and Gordon C. (2004b), 'Conditionality and Compliance in the EU's Eastward Enlargement: Regional Policy and the Reform of Sub-national Government', Journal of Common Market Studies 42(3): 523-51.

Human Rights Watch (2008) These Everyday Humiliations: Violence against Lesbians, Bisexual Women, and Transgender Men in Kyrgyzstan. New York, NY: Human Rights Watch. 
IRIN (2004) 'Tajikistan: Gay rights face uphill struggle'. Online. Available HTTP: <http://www.irinnews.org/report.aspx? reportid=24445> (accessed 21 November 2011).

Jenness, V. (2004) 'Explaining Criminalization: From Demography and Status Politics to Globalization and Modernization', Annual Review of Sociology, 30: 141-171.

Jordan, P. (2003) 'Does Membership Have Its Privileges? Entrance into the Council of Europe and Compliance with Human Rights Norms', Human Rights Quarterly 25: 660688.

Kelley, J. (2004) 'International Actors on the Domestic Scene: Membership Conditionality and Socialization by International Institutions', International Organization 58: 425-457.

Killick, T. with Gunatilaka, R. and Marr, A. (1998) Aid and the Political Economy of Policy Change. London: Routledge.

Klebanov, L. (2006) 'Desyat' let ugolovnomu kodeksu Rossiiskoi Federatsii: dostoinstva i nedostatki', Gosudarstvo i Pravo 9: 107-114.

Kochenov, D. (2008) EU Enlargement and the Failure of Conditionality: Pre-Accession Conditionality in the Fields of Democracy and the Rule of Law. Alphen aan den Rijn: Kluwer Law International. 
Kon, I. (1993) 'Sexual Minorities', in Kon, I. and Riordan, J. (eds) Sex and Russian Society. Bloomington, IN; Indianapolis, IN: Indiana University Press.

Kon, I. (1997) 'Russia', in West, D. and Green, R. (eds) Sociolegal Control of Homosexuality: A Multi-Nation Comparison.

Korableva, M. (2003) 'A Comparative Study of the Protection of Civil Rights: The Civil Codes of CIS Countries', Review of Central and East European Law 28(2): 167182.

Lacey, N. (2009) 'Historicising Criminalisation: Conceptual and Empirical Issues', Modern Law Review 72: 936-961.

Lalo, A. and Schitov, N. (2005) 'Sexualities in Belarus: Some Major Patterns of Sexual Behaviour and Their Cultural Background', in Štulhofer, A. and Sandfort, T. (eds), Sexuality and Gender in Postcommunist Eastern Europe and Russia. Binghamton, NY: The Haworth Press.

Long, S. (Human Rights Watch and the International Gay and Lesbian Human Rights Commission) (1998) Public Scandals: Sexual Orientation and Criminal Law in Romania: A Report. London; New York, NY: Human Rights Watch.

Luneev, V. (2005) Prestupnost' XX veka: mirovye, regionalnye i Rossiiskie tendentsii. Moscow: Walters Kluwer. 
McLoughlin, M. (1996) 'Crystal or Glass? A Review of Dudgeon v. United Kingdom on the Fifteenth Anniversary of the Decision', Murdoch University Electronic Journal of Law 3(4).

Maffucci-Hugel, C. Former Co-Secretary of the Committee on Legal Affairs and Human Rights of the Parliamentary Assembly of the Council of Europe. Transcript of a research interview carried out for Noble (2010) in the Palais d'Europe on 18 September 2009.

Manas, J. (1996) 'The Council of Europe's Democracy Ideal and the Challenge of Ethno-National Strife', in Chayes, A. and Chayes, A. (eds) Preventing Conflict in the Post-Communist World: Mobilising International and Regional Organizations. Washington, DC: Brookings Institution.

Markovits, I. (2004) 'Exporting Law Reform - But Will It Travel?', Cornell International Law Journal 37: 95-114.

Meron, T. and Sloan, J. (1996) 'Democracy, Rule of Law and Admission to the Council of Europe', Israel Yearbook on Human Rights 26.

Modinos v. Cyprus (1993) 16 E.H.R.R. 485. Cited here from the judgment of the Court (Chamber), 22 April. Online. Available HTTP: 
<http://cmiskp.echr.coe.int/tkp197/view.asp?item=1\&portal=hbkm\&action=html\&highl $\underline{\text { ight }}=$ modinos \&sessionid $=52854353 \&$ skin $=$ hudoc-en $>($ accessed 21 November 2011$)$.

Nachescu, V. (2005) 'Hierarchies of Difference: National Identity, Gay and Lesbian Rights, and the Church in Postcommunist Romania', in Štulhofer, A. and Sandfort, T. (eds) Sexuality and Gender in Postcommunist Eastern Europe and Russia. Binghamton, NY: The Haworth Press.

Nash Mir (2004). Ukrainian gay men and lesbians at the threshold of the Millennium. Kiev: Nash Mir.

Newton, S. (2003) 'Transplantation and Transition: Legality and Legitimacy in the Kazakhstani Legislative Process', in Galligan, D. and Kurkchiyan, M. (eds) Law and Informal Practices: The Post-Communist Experience. Oxford; New York, NY: Oxford University Press.

Noble, B. (2010) Decriminalising Sodomy in the Former Soviet Union, 1991-2003, unpublished MPhil Russian and East European Studies thesis, University of Oxford.

Norris v. Ireland (1988) 13 E.H.R.R. 186. Cited here from the judgment of the Court (Plenary), 26 October. Online. Available HTTP:

<http://cmiskp.echr.coe.int/tkp197/view.asp?item=1\&portal=hbkm\&action=html\&highl

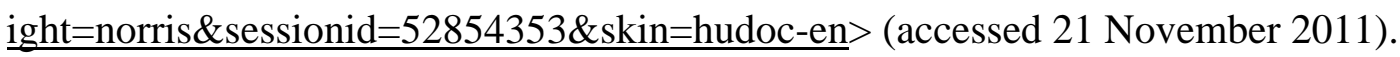


Official in the Office of the Commissioner for Human Rights, Council of Europe. Transcript of a research interview carried out for Noble (2010) in the Palais d'Europe on 16 September 2009.

Ottosson, D. (2008) State-Sponsored Homophobia: A world survey of laws prohibiting same sex activity between consenting adults. ILGA. Online. Available HTTP: < http://ilga.org/Statehomophobia/ILGA_State_Sponsored_Homophobia_2008.pdf $>$ (accessed 21 November 2011).

PACE Opinion No. 188 (1995) 'Application by Moldova for membership of the Council of Europe'. Online. Available HTTP:

<http://assembly.coe.int/main.asp?Link=/documents/adoptedtext/ta95/eopi188.htm>.

PACE Opinion No. 221 (2000) 'Armenia's application for membership of the Council of Europe'. Online. Available HTTP:

<http://assembly.coe.int/main.asp?Link=/documents/adoptedtext/ta00/eopi221.htm> (accessed 21 November 2011).

PACE Opinion No. 222 (2000) 'Azerbaijan's application for membership of the Council of Europe'. Online. Available HTTP:

<http://assembly.coe.int/main.asp?Link=/documents/adoptedtext/ta00/eopi222.htm $>$ (accessed 21 November 2011). 
PACE Resolution 1304 (2002) 'Honouring of obligations and commitments by Armenia'. Online. Available HTTP:

< http://assembly.coe.int/Main.asp?link=/Documents/AdoptedText/ta02/ERES1304.htm $>$ (accessed 21 November 2011).

Pashin, S. (2001) 'The Reasons for Reintroducing Trial by Jury in Russia', Revue internationale de droit penal 72(1): 253-257.

Peshkopia, R. and Imami, A. (2008) 'Between Elite Compliance and State Socialization: The Abolition of the Death Penalty in Eastern Europe', The International Journal of Human Rights 13(3): 353-372.

Pierson, P. (2005) 'The Study of Policy Development', Journal of Policy History 17(1): 34-51.

Pravda, A. (2001) 'Introduction', in Zielonka, J. and Pravda, A. (eds) Democratic Consolidation in Eastern Europe: International and Transnational Factors. Oxford; New York, NY: Oxford University Press.

Recommendation 924 (1981) 'On discrimination against homosexuals', adopted 1 October. Online. Available HTTP:

$<\underline{\text { http://assembly.coe.int/main.asp?Link=/documents/adoptedtext/ta81/erec924.htm }>}$ (accessed 21 November 2011). 
Recommendation 1474 (2000) 'Situation of lesbians and gays in Council of Europe member states', adopted 26 September. Online. Available HTTP:

$<\underline{\text { http://assembly.coe.int/main.asp?Link=/documents/adoptedtext/ta00/erec1474.htm }>}$ (accessed 21 November 2011).

Saari, S. (2008) 'Russia's Creeping Challenge to European Norms: European Promotion of Abolition of the Death Penalty in Russia', in Hopf, T. (ed.) Russia's European Choice. Basingstoke; New York, NY: Palgrave Macmillan.

Sanders, D. (2002) 'Human Rights and Sexual Orientation in International Law', International Journal of Public Administration 25(1): 13-44.

Sasse, G. (2008) 'The politics of EU conditionality: the norm of minority protection during and beyond EU accession', Journal of European Public Policy 15(6): 842-860.

Sasse, G. (2009) 'Tracing the construction and effects of EU conditionality', in Rechel, B. (ed.) Minority Rights in Central and Eastern Europe. Abingdon; New York, NY: Routledge.

Sasse, G. (2011) 'The Council of Europe as a Norm Entrepreneur: The Political Strengths of a Weak International Institution', in Walker, N., Shaw, J. and Tierney, S. (eds) Europe's Constitutional Mosaic. Oxford; Portland, OR: Hart. 
Schieder, P. (2009), speech made at the conference, 'The Global Arc of Justice', California State University, Los Angeles, 14 March 2009.

Schimmelfennig, F. (2007) 'European Regional Organizations, Political Conditionality, and Democratic Transformation in Eastern Europe', East European Politics and Societies 21(1): 126-141.

Schimmelfennig, F., Engert, S. and Knobel, H. (2006) International Socialization in Europe: European Organizations, Political Conditionality, and Democratic Change. Basingstoke: Palgrave Macmillan.

Senior official in the Directorate of Democracy and Political Affairs, Council of Europe. Transcript of a research interview carried out for Noble (2010) in the Palais d'Europe on 21 September 2009.

Simpson, A. (2001) Human Rights and the End of Empire: Britain and the Genesis of the European Convention. Oxford: Oxford University Press.

Smirnov, A.M. (2011) Istoriya gosudarstvennogo presledovaniya $i$ prestupnosti $v$ otnoshenii lits s seksual'nymi inversiyami v zarubezhnykh stranakh i Rossii. Moscow: Iurlitinform. 
Statute of the Council of Europe (1949). Online. Available HTTP:

<http://conventions.coe.int/Treaty/en/Treaties/html/oo1.htm> (accessed 21 November 2011).

Stites, R. (1991) The Women's Liberation Movement in Russia: Feminism, Nihilism, and Bolshevism, 1860-1930. Princeton, NJ: Princeton University Press.

Storey, H. (1995) 'Human Rights and the New Europe: Experience and Experiment', Political Studies 43: 131-151.

Strang, D. and Meyer, J. (1993) 'Institutional conditions for diffusion', Theory and Society 22: 487-511.

Štulhofer, A. and Sandfort, T. (2005) 'Introduction: Sexuality and Gender in Times of Transition', in Štulhofer, A. and Sandfort, T. (eds), Sexuality and Gender in Postcommunist Eastern Europe and Russia. Binghamton, NY: The Haworth Press.

Stychin, C. (2003) “We want to join Europe, not Sodom': Sexuality and European Union Accession in Romania', in Stychin, C. (2003) Governing Sexuality: The Changing Politics of Citizenship and Law Reform Oxford: Hart.

Tansey, O. (2007) 'Process Tracing and Elite Interviewing: A Case for Non-probability Sampling', Political Science and Politics 40(4): 765-772. 
Tarschys, D. (1995) 'The Council of Europe: the Challenge of Enlargement', The World Today 51(4).

Tatchell, P. (1992) Europe in the Pink: Lesbian and Gay Equality in the New Europe. London: GMP Publishers.

Thaman, S. (1995) 'The Resurrection of Trial by Jury in Russia', Stanford Journal of International Law 31(1): 61-274.

Tornow, S. (1991) 'Homosexuality and Politics in Soviet Russia', in Veispak, T. and Parikas, U. (eds) (1991) Sexual Minorities and Society: The Changing Attitudes toward Homosexuality in 20 ${ }^{\text {th }}$ Century Europe. Tallinn: Eesti Teaduste Akadeemia Ajaloo Instituut.

Torra, M. (1998) 'Gay Rights After the Iron Curtain', The Fletcher Forum of World Affairs 22(2): 73-87.

Turescu, L. and Stan, L. (2005) 'Religion, Politics and Sexuality in Romania', EuropeAsia Studies 57(2): 291-310.

Vachudova, M. (2005) Europe Undivided: Democracy, Leverage and Integration after Communism. New York, NY: Oxford University Press. 
Veispak, T. (1991) 'Homosexuality in Estonia in the $20^{\text {th }}$ Century: Ideological and Juridical Aspects', in Veispak, T. and Parikas, U. (eds) Sexual Minorities and Society: The Changing Attitudes toward Homosexuality in $20^{\text {th }}$ Century Europe. Tallinn: Eesti Teaduste Akadeemia Ajaloo Instituut.

Waaldijk, K. (2000) 'Civil Developments: Patterns of Reform in the Legal Position of Same-Sex Partners in Europe', Canadian Journal of Family Law 17: 62-88.

Warner, N., ILGA-Europe Council of Europe adviser. Transcript of a research interview carried out for Noble (2010) on 4 August 2009.

Way, L., and Levitsky, S. (2007) 'Linkage, Leverage, and the Post-Communist Divide', East European Politics and Societies 21(1): 48-66.

Weeks, J., Professor at London South Bank University. Transcript of a research interview carried out for Noble (2010) in London on 9 September 2009.

Written Declaration 227 (1993) 'On homosexual rights in the new democracies', signed on 18 February. Online. Available HTTP:

<http://assembly.coe.int/Mainf.asp?link=/Documents/WorkingDocs/Doc93/EDOC6779. $\underline{\text { htm }}>$ (accessed 21 November 2011).

${ }^{1}$ This chapter is based on research for the author's MPhil thesis in Russian and East European Studies, University of Oxford, 2010. The author would like to thank Harold 
Carter, Paul Chaisty, Kay Goodall, Carol Leonard, Margaret Malloch, Gwen Sasse, and Peter Solomon for their many helpful comments and suggestions. Parts of the chapter were written during the author's tenure of an Alfa Fellowship in Moscow; he gratefully acknowledges the Alfa Fellowship Program's generous support.

${ }^{2}$ Ukraine was the only state to decriminalise before the formal dissolution of the Union of Soviet Socialist Republics (USSR).

${ }^{3}$ The Russian term for this activity, muzhelozhstvo, is often translated as 'sodomy' or 'pederasty', and defined as 'sexual intercourse of a man with a man'.

${ }^{4}$ Dudgeon v. United Kingdom (1981) 4 E.H.R.R. 149. This judgment was affirmed in Norris v. Ireland (1988) 13 E.H.R.R. 186 and Modinos v. Cyprus (1993) 16 E.H.R.R. 485.

${ }^{5}$ As will be demonstrated below, however, there is a significant difference between a technical condition of membership and a condition which is clear, determinate, and politically visible during accession processes.

${ }^{6}$ See also, for example, Capoccia and Ziblatt (2010), Gerring (2007), and Hall (2008) on the key role of analysing causal mechanisms for analytic leverage in causal inference.

7 This method is congruent with an ontological understanding of conditionality as a complex process rather than a 'clear-cut phenomenon' (Sasse 2009: 17). Kelley's (2004: 426) work also demonstrates the gains made from analysing particular areas of policy, rather than simply 'broad democratic trends', as seen, for example, in Schimmelfennig (2007).

${ }^{8}$ Individuals were selected by a combination of chain-referral (snowball) sampling (Tansey 2007), and reputational and positional sampling. 
${ }^{9}$ For more details on the methodology, research design, and data used in this research, see Noble (2010).

${ }^{10}$ The Romanian case of vociferous contestation accords with expectations that cultural dissonance, or a value 'mis-match', will hamper norm diffusion - see, for example, Strang and Meyer (1993) and Checkel (1999). According to Stychin (2003: 122), this cultural barrier in Romania was only overcome as a result of subsequent EU conditionality.

11 As Epstein (2008) notes, we would imagine this continued contestation by Council member states to weaken the credibility of the norm centred around Dudgeon, thereby reducing the CoE's authority to push for compliance in accession states.

${ }^{12}$ For richly detailed examinations of this history, see in particular Healey (2001) and Engelstein (1995). See also Smirnov (2011) and Chapter 2 of Noble (2010); see Tatchell (1992) for short histories of East European states and the emergence of sexual minority social movements towards the end of the communist era.

13 This criminalisation applied to all new territories on incorporation into the Union. The Baltic states' histories regarding the legal regulation of sex between men has received less scholarly attention. The available information is, therefore, patchy. According to Lavrikovs (EURO-Letter 43, 1996), all three states decriminalised in the inter-war period, with recriminalisation on their forced inclusion into the USSR in 1940. This account of inter-war decriminalisation is supported by Veispak (1991: 108), but only for Estonia. Further research is required.

${ }^{14}$ Kurs sovetskogo ugolovnogo prava: chast' osobennaya (Leningrad: Leningrad State University Press). Quoted in Gessen (1994: 9-10). 
15 Professor Jeffrey Weeks - a leading Western sociologist and delegate at the conference - noted participants from Estonia, Latvia, Lithuania, and Russia, as well as nationals from Austria, Britain, Denmark, Finland, Germany, the Netherlands, Sweden, and the United States.

16 This can be contrasted with the Conference on Security and Cooperation in Europe (CSCE) (later the Organization for Security and Cooperation in Europe (OSCE)), which carried out the most 'inclusive' post-communist enlargement.

17 This strategy can be contrasted with the EU's 'exclusive' approach to enlargement: use the 'carrot' of membership to pressure compliance with EU conditions by keeping applicants 'out of the club'.

${ }^{18}$ Similarly, Schimmelfennig, Engert and Knobel (2006: 41) write that the CoE 'likes to portray itself as 'Europe's democratic conscience'.

${ }^{19}$ Killick (1998) names this latter 'modality' of conditionality 'residual conditions'.

${ }^{20}$ Despite being the clearest list of conditions, these accession commitments were in many respects associated with the least leverage, since satisfying them was expected after membership had been granted (see Killick 1998).

${ }^{21}$ This was the CoE programme of reform assistance extended to 'special guest status' states from the FSU.

${ }^{22}$ Belarus' 'special guest status' was suspended by PACE in January 1997.

${ }^{23}$ As the research on which this chapter is based makes clear, the activities of the NGO ILGA - and, more specifically, ILGA-Europe from 1996 - were crucial in providing information for the Council of Europe on the legal status of sexual minorities in postSoviet states (as well as further afield), thereby maintaining the visibility of the politically contested norm established around the ECHR by Dudgeon v. UK; they also 
lobbied the Council for an explicit inclusion of non-criminalisation as a condition of CoE membership.

${ }^{24}$ Emphasis added.

${ }^{25}$ Fellmeth (2008: 822) is mistaken, therefore, in arguing that PACE announced in 2000 'a policy of accepting for membership only those states that had abolished criminal prohibitions on homosexual intercourse'. Rather, point 4 of Recommendation 1474 is an incorrect characterisation of existing Council policy regarding the place of the decriminalisation of sex between men in accession procedures, as shown, for example, by the earlier accession of Georgia and the later accession of Armenia.

${ }^{26}$ We would not, clearly, expect to find a reference in Ukraine's accession materials, given its early decriminalisation.

${ }^{27}$ However, the constancy suggested by this remark is contradicted somewhat by the language, for example, in the CLAHR opinion on Moldova's application for membership cited above. Here, it seems that their attention was brought to the law criminalising sex between men not by the sub-committee, but by an NGO: ILGAEurope.

${ }^{28}$ See Drzemczewski $(1993,1995)$ for an overview of Council assistance programmes early in enlargement.

${ }^{29}$ In a slight variation, Levitsky and Way (2006: 379) prefer to call these more 'diffuse effects' 'linkage' rather than 'leverage'.

${ }^{30}$ For more details, see Chapter 4 of Noble (2010), with a particularly detailed section on the Russian reform process. 
${ }^{31}$ This insulated reform process helps explain a more general finding by Adamczyk and Pitt (2009) that there is no statistically significant relationship between public attitudes and the legal regulation of sex between men on a global level.

${ }^{32}$ The precise details of the decriminalisation processes for these states require further investigation.

${ }^{33}$ On the wider role of the IPA-CIS's Model Criminal Code as an influential document for reform in post-Soviet states, see Klebanov (2006) and Luneev (2005: 199-279). For the IPA-CIS's Model Civil Code's influence, see Korableva (2003).

${ }^{34}$ Despite Kon's (1997: 229) assertion that Russia decriminalised as a result of 'strong pressure from Western public opinion and in order to obtain a place in the Council of Europe', no evidence is provided to support this claim. See also Smirnov (2011: 154) for a similarly unsupported claim about the influence of the Council. Moreover, Healey (2001: 249) is wrong to assert that this decriminalisation was the result of a presidential decree (ukaz): the RSFSR criminal code was amended by a federal law, signed by President Yeltsin on 29 April 1993.

${ }^{35}$ See Capoccia and Kelemen (2007) for a discussion of this concept within the context of historical institutionalism.

${ }^{36}$ See, also, the literature on the reintroduction of jury trials in Russia for another case of disputed legal aetiology: for example, Bowring (2003); De Muniz (2004); Pashin (2001); and Thaman (1995). See Markovits (2004), however, for a critique. 